acetate was consistently found to lower the GSH content, the fall in GSH being greater as the dose of acetoacetate increased.

2. The GSH level could be reduced to zero after repeated injection of acetoacetate.
The authors record their grateful thanks to the Indian Council of Medical Research for the award of a Research Fellowship to one of them (V.G.H.).

They are also thankful to Shri V. K. Sahu for his help in determining the blood-sugar values recorded in Fig. 1.

\title{
REFERENCES
}

Campanacci, D. (1930). Klin. Wschr. 9, 1212.

Conn, J. W., Louis, L. H. \& Wheeler, C. E. (1948). J. lab. clin. Med. 33, 651.

Goss, H. \& Gregory, P. W. (1935). Proc. Soc. exp. Biol., N.Y., 32, 681.

Gregory, P. W. \& Goss, H. (1939). Growth, 3, 159.

Grunert, R. R. \& Phillips, P. H. (1949). J. biol. Chem. 181, 821.

Hagedorn, H. C. \& Jensen, B. N. (1923). Biochem. Z. 135, 46.

Illing, E. K. B., Gray, C. H. \& Lawrence, R. D. (1951). Biochem. J. 48, 637.

Lazarow, A. (1949). Physiol. Rev. 29, 48.
Leech, R. S. \& Bailey, C. C. (1945). J. biol. Chem. 157, 525.

Nath, M. C. \& Brahmachari, H. D. (1944). Nature, Lond., $154,487$.

Nath, M. C. \& Brahmachari, H. D. (1949). Ind. J. med. Res. 37, 71.

Nath, M. C. \& Chakrabarti, C. H. (1950). Proc. Soc. exp. Biol., N.Y., 75, 326.

Nath, M. C. \& Chakrabarti, C. H. (1951). Proc. Soc. exp. Biol., N.Y., 78, 369.

Nath, M. C. \& Hatwalne, V. G. (1950). Nature, Lond., 166, 692.

Woodward, G. E. \& Fry, E. G. (1932). J. biol. Chem. 97, 465.

\section{Studies on Alloxan Diabetes}

\section{INCREASE OF SUSCEPTIBILITY CAUSED BY ACETOACETATE}

\author{
By M. C. NATH, J. S. GADGIL AND V. G. HATWALNE \\ The University Department of Biochemistry, Nagpur, India
}

(Received 5 August 1952)

Acetoacetate, which has been found in this laboratory to cause hyperglycaemia (Nath $\&$ Brahmachari, 1944), to reduce glucose tolerance (Nath \& Chakrabarti, 1950), to raise blood lactic acid (Nath \& Chakrabarti, 1951) and to inactivate insulin both in vitro and in vivo (Nath \& Brahmachari, 1946), has recently been reported to cause decrease in the reduced glutathione (GSH) content of blood by Nath \& Hatwalne (1950) and Nath, Hatwalne \& Gadgil (1953). Griffiths (1948, 1950), in his studies on the production of diabetes by the administration of uric acid, noticed that diabetes could be produced in the animals only when the blood GSH level could be lowered by a diet deficient in cysteine and methionine and by feeding a large amount of ascorbic acid, which was shown by Prunty \& Vass (1943) to lower the glutathione content of the blood, and to increase the susceptibility of rats to alloxan diabetes (cf. Lazarow, 1946). The increased sensitivity of starved animals to the diabetogenic action of alloxan, as noticed by Kass \& Waisbren (1945), might be due to the fall of blood GSH which takes place during starvation (Hirano, 1934). It is also worth noting that animals depleted in

Table 1. Effect of acetoacetate injection on the lowering of blood GSH and increase of blood sugar

(Average values with the calculated mean deviations.)

\begin{tabular}{|c|c|c|c|c|}
\hline \multirow[b]{2}{*}{$\begin{array}{c}\text { Group } \\
\text { no. }\end{array}$} & \multirow[b]{2}{*}{$\begin{array}{l}\text { No. of } \\
\text { animals in } \\
\text { the group }\end{array}$} & \multicolumn{2}{|c|}{ Blood GSH (mg./100 ml.) } & \multirow[b]{2}{*}{$\begin{array}{c}\text { Blood sugar } \\
\text { of the treate } \\
\text { animals } \\
\text { (mg./100 ml. }\end{array}$} \\
\hline & & Initial & $\begin{array}{c}\text { After injection } \\
\text { of acetoacetate } \\
\text { for } 5 \text { weeks } \\
\text { (150 mg. } / \mathrm{kg} .)\end{array}$ & \\
\hline $\begin{array}{l}\text { I } \\
\text { II } \\
\text { III } \\
\text { IV } \\
\text { V }\end{array}$ & $\begin{array}{l}6 \\
6 \\
6 \\
6 \\
6 \\
6\end{array}$ & $\begin{array}{l}28 \cdot 8 \pm 3 \cdot 6 \\
27 \cdot 8 \pm 3 \cdot 8 \\
31 \cdot 3 \pm 3 \cdot 9 \\
30 \cdot 7 \pm 2 \cdot 9 \\
28 \cdot 8 \pm 3 \cdot 4\end{array}$ & $\begin{array}{l}2 \cdot 7 \pm 0 \cdot 1 \\
2 \cdot 5 \pm 0 \cdot 2 \\
2 \cdot 7 \pm 0 \cdot 2 \\
2 \cdot 5 \pm 0 \cdot 7 \\
2 \cdot 7 \pm 0.5\end{array}$ & $\begin{array}{l}131 \cdot 8 \pm 4 \cdot 9 \\
131 \cdot 0 \pm 3 \cdot 1 \\
134 \cdot 0 \pm 2 \cdot 7 \\
133 \cdot 0 \pm 3 \cdot 6 \\
133 \cdot 0 \pm 4 \cdot 4\end{array}$ \\
\hline
\end{tabular}

Biochem. 1953, 53 
blood GSH by a sodium-deficient diet have also been shown to have increased susceptibility to alloxan (Grunert \& Phillips, 1949).

Archibald (1945) and Lazarow, Patterson \& Levy (1948) have shown that when alloxan is administered it undergoes destruction partly by the glutathione of the blood and partly by other mechanisms. When the dose is high, some of it reaches the $\beta$ cells of the pancreas and reacts with the glutathione of these $\beta$ cells and even causes cell death by reacting with the sulphydryl groups of the protein and the enzymes. It is, therefore, expected that any substance which would decrease GSH in the body would also increase the susceptibility to alloxan.

This work was undertaken to see whether acetoacetate, which can produce various diabetic symptoms and can cause reduction of blood GSH, can cause an increase in the susceptibility to alloxan.

\section{EXPERIMENTAL}

Thirty male rabbits weighing $1 \cdot 5-2 \mathrm{~kg}$. were selected and divided into five groups of six and their normal blood GSH was determined by the method of Woodward \& Fry (1932). They were then injected subcutaneously with $150 \mathrm{mg}$. $/ \mathrm{kg}$. of sodium acetoacetate daily for 5 weeks, when usually all the animals had turned over from their initial hypoglycaemic to the hyperglycaemic state (Nath \& Chakrabarti, 1950). Blood sugar was estimated by the method of Hagedorn \& Jensen (1923). After 5 weeks, when the animals in all the five groups were found to have very low blood GSH, those in one group were kept as control while those in other groups were injected intravenously with different doses of alloxan after allowing them to fast for about $18 \mathrm{hr}$. Twenty-four normal rabbits were also used to ascertain the diabetogenic and lethal doses of alloxan on the normal animals in our laboratory.

\section{RESULTS AND DISCUSSION}

Table 1 shows that animals in all the groups show a slight rise in the fasting blood-sugar level and a sharp decline in the blood GSH content on injection of acetoacetate for 5 weeks. Urine of all the animals was analysed at this time and none was found to contain glucose, ketone bodies or albumin.

It will be evident from Table 2 that although a dose of $25 \mathrm{mg} . / \mathrm{kg}$. of alloxan is absolutely without any effect, those having $50 \mathrm{mg} . / \mathrm{kg}$. showed a definite tendency to have hyperglycaemia without glycosuria. A dose of $75 \mathrm{mg}$./kg., however, produced marked increase in the blood sugar with glycosuria and acetonuria and also albuminuria in some cases. A dose of $100 \mathrm{mg}$. $/ \mathrm{kg}$. was found fatal to about $80 \%$ of the animals who died within $48 \mathrm{hr}$., the only one surviving showing blood sugar as $410 \mathrm{mg} . / 100 \mathrm{ml}$. and $4.5 \%$ sugar in urine. The test for acetone in the urine was strongly positive and the albumin content high.

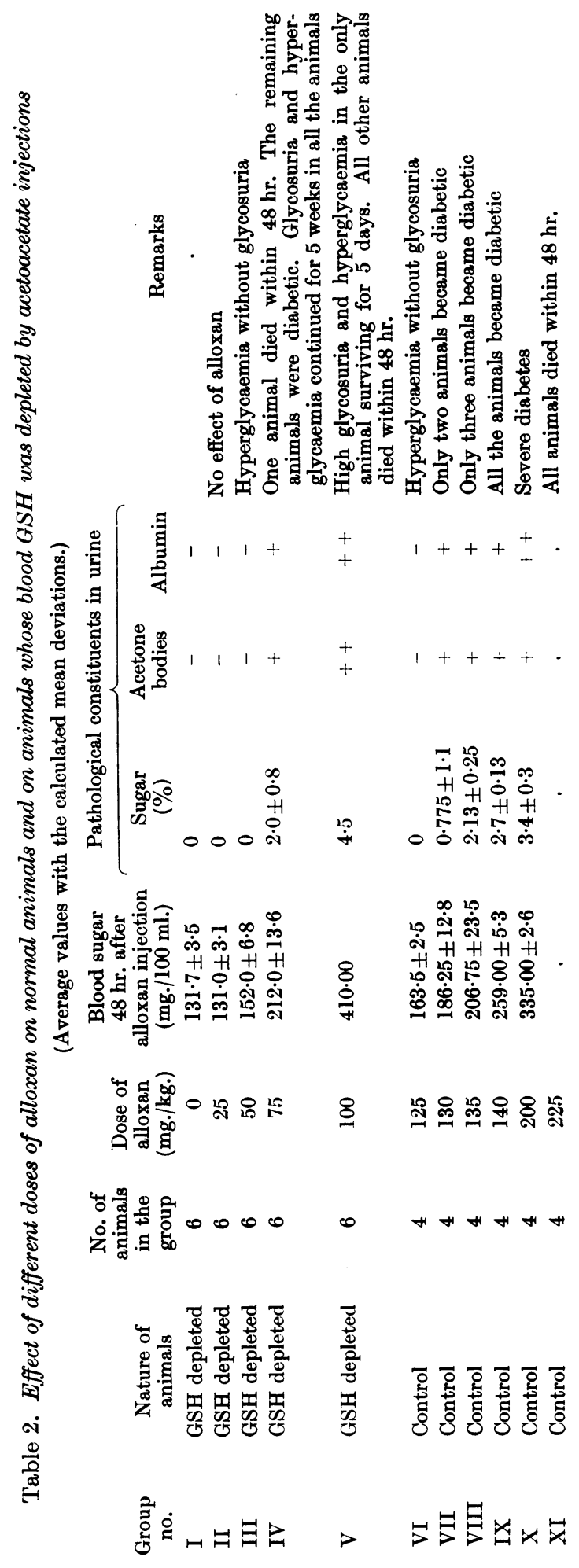


From Table 2 it will also be seen that the diabetogenic dose of alloxan in normal animals, as found in this laboratory, ranges between 130 and $140 \mathrm{mg} \cdot / \mathrm{kg}$. and the lethal dose is observed to be in the neighbourhood of $225 \mathrm{mg} . / \mathrm{kg}$. It is interesting to note that the diabetogenic and lethal doses of alloxan in acetoacetate-treated animals, having blood GSH in the neighbourhood of $3 \mathrm{mg} . / 100 \mathrm{ml}$., are only 75 and $100 \mathrm{mg} . / \mathrm{kg}$., respectively. Continued injection of acetoacetate for a few weeks has thus a definite effect in making the animals susceptible to alloxan.

It may be mentioned here that the diabetogenic and lethal doses of alloxan in normal animals, as quoted by Lukens (1948) and others, are 150-200 and $300 \mathrm{mg} . / \mathrm{kg}$., respectively, which are somewhat higher than the values observed by us. The dis- parity may be explained by the difference in diet, climate and breed of the animals.

\section{SUMMARY}

1. Rabbits injected subcutaneously with $150 \mathrm{mg}$./ kg. sodium acetoacetate daily for 5 weeks show a slight rise in blood sugar, and an enormous fall in reduced glutathione in blood.

2. The susceptibility of these treated animals to alloxan is increased to a great extent, $75 \mathrm{mg} . / \mathrm{kg}$. being the diabetogenic dose and $100 \mathrm{mg} . / \mathrm{kg}$. the lethal dose, as compared with 130-150 and $225 \mathrm{mg}$./ kg., respectively, for controls.

The authors record their grateful thanks to the Indian Council of Medical Research for the award of a Research Fellowship to one of them (V.G.H.).

\title{
REFERENCES
}

Archibald, R. M. (1945). J. biol. Chem. 158, 347.

Griffiths, M. (1948). J. biol. Chem. 172, 853.

Griffiths, M. (1950). J. biol. Chem. 184, 289.

Grunert, R. R. \& Phillips, P. H. (1949). J. biol. Chem. 181, 821.

Hagedorn, H. C. \& Jensen, B. N. (1923). Biochem. Z. 135, 46.

Hirano, Y. (1934). Orient. J. Dis. Inf. 16, 25.

Kass, E. H. \& Waisbren, B. A. (1945). Proc. Soc. exp. Biol., N.Y., 60, 303.

Lazarow, A. (1946). Proc. Soc. exp. Biol., N.Y., 61, 441.

Lazarow, A., Patterson, J. W. \& Levy, S. (1948). Science, $108,308$.

Lukens, F. D. W. (1948). Physiol. Rev. 28, 304.
Nath, M. C. \& Brahmachari, H. D. (1944). Nature, Lond., 154, 487.

Nath, M. C. \& Brahmachari, H. D. (1946). Nature, Lond., 157, 336.

Nath, M. C. \& Chakrabarti, C. H. (1950). Proc. Soc. exp. Biol., N.Y., 75, 326.

Nath, M. C. \& Chakrabarti, C. H. (1951). Proc. Soc. exp. Biol., N.Y., 78, 369.

Nath, M. C. \& Hatwalne, V. G. (1950). Nature, Lond., 166, 692.

Nath, M. C., Hatwalne, V. G. \& Gadgil, J.S. (1953). Biochem. J. 53, 479.

Prunty, F. T. G. \& Vass, C. C. N. (1943). Biochem. J. 37, 506.

Woodward, G. E. \& Fry, E. C. (1932). J.biol. Chem. 97, 465.

\section{The Assimilation of Amino-acids by Bacteria}

\section{NUCLEIC ACID AND PROTEIN SYNTHESIS IN STAPHYLOCOCCUS AUREUS}

\author{
BY E. F. GALE AND JOAN P. FOLKES \\ Medical Research Council Unit for Chemical Microbiology, Biochemical Laboratory, \\ University of Cambridge
}

(Received 22 May 1952)!

If washed suspensions of. Staphylococcus aureus (Micrococcus pyogenes var. aureus) are incubated in buffered salt solution containing glucose and glutamic acid, free glutamic acid accumulates to a high concentration within the cell (Gale, 1947a,b). If certain other amino-acids, such as cysteine or alanine, are added singly to the incubation mixture, the accumulation of free glutamic acid within the cells is reduced while peptides of glutamic acid appear in the external medium (Gale \& Van Halteren, 1951). If a complete mixture of amino- acids and glucose is present, then the cells no longer accumulate free glutamic acid but the combined glutamate of the cellular substance increases, glutamic acid from inside and outside the cell becoming directly incorporated into this combined glutamate fraction (Gale, 1951 b).

In the investigations so far described in this series, no account has been taken of the nucleic acid content of the cells or of its variation. In the present work, the nucleic acid content has been studied and the effect of the addition of purines and 